ФІЗИЧНЕ ВИХОВАННЯ РІЗНИХ ГРУП НАСЕЛЕННЯ

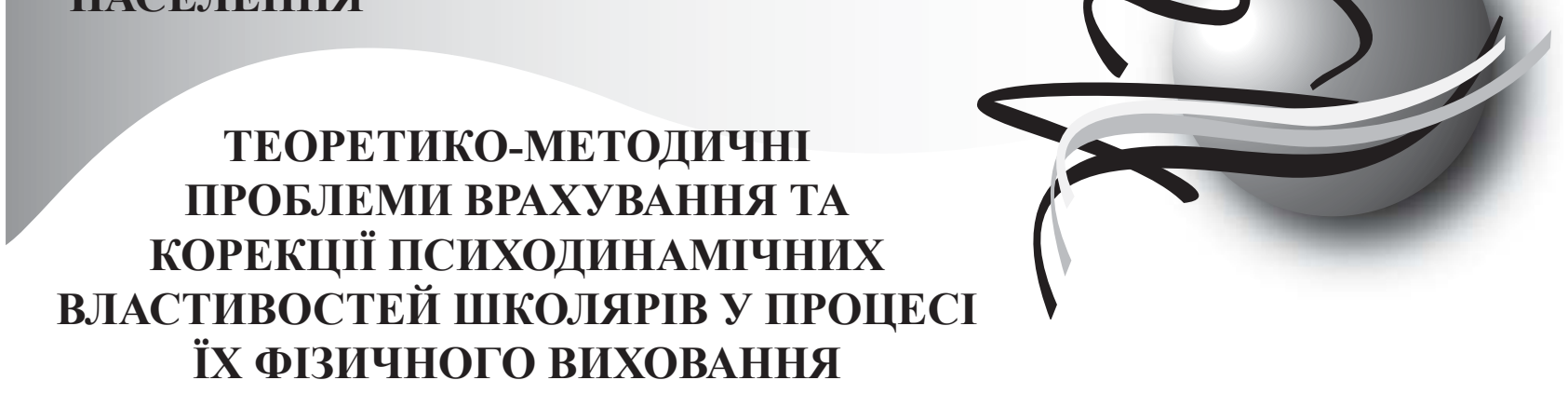

\author{
'Бондарчук Наталія, 'Чернов Biкmор, 'Kalabiska Irina \\ 'Ужгородський національний університет, \\ ${ }^{2}$ University of Physical Education \\ Research Center for Sport Physiology
}

\title{
DOI: 10.32540/2071-1476-2019-4-111
}

\section{Annotation}

Introduction. Every person is a unique person from birth; this increases the urgency of the problem of respecting the personality of each school pupil, its various manifestations, using differentiated and individual approaches in the process of education. To a large extent, the pupil's personality is manifested in its psychodynamic properties, and first these are temperament properties, on which the speed and intensity of mental processes, the pace and rhythm of activity, its evaluation and self-control depend. The relevance of the account of psychodynamic properties in the physical education of school pupils is connected with the fact that such an account will make it possible to optimize pedagogical work in physical education classes and introduce differentiated and individual approaches into the process of physical education. To date, the effect of the psychodynamic properties of school pupils on the possibilities of their physical development has not been studied, and pedagogical means of correction of the manifestations of these properties in the process of physical education has not been developed.

The purpose of the study: on the basis of study of literary sources to determine the psychodynamic properties of children and adolescents of school age, to characterize theoretical and methodological problems and develop appropriate bases for their physical education, taking into account these properties, and also methods and means of their correction for leveling the negative and stimulating the positive features of certain types of school pupil's temperament.

Material and methods: analysis and synthesis of literary sources.

Results. In the article there are analyzed basic psychodynamic properties of human, which are temperament, sensitiveness, and dynamic aspects of behavior, at the same time, the main attention is focused on the manifestations of temperament properties. The author emphasizes that children have their own characteristics of manifestation of psychodynamic properties, in particular temperament, and these features depend on the properties of the nervous system. The article discusses the relationship between mental and psychodynamic properties of school pupils. It states that such physical qualities as quickness, endurance, and strength of pupils depend, among other things, on the type of temperament. There is showed important aspects of pedagogical work with school pupils with different psychodynamic properties. The solution of specific pedagogical tasks in physical education classes should be coordinated with the psychodynamic properties of pupils, which are especially pronounced in joint activities in the process of physical education. The optimal variants of the compatibility of various temperament properties of schoolchildren are given. There are developed criteria for taking into account the psychodynamic properties of pupils in the development of various physical qualities, appropriate means of pedagogical influence on children and adolescents with different types of temperament. The author suggests methods and means for correcting the psychodynamic properties of school pupils in physical education classes.

Conclusions. The teacher of physical culture should have knowledge of the links between specific psychodynamic properties and different personal qualities, characteristics, abilities of pupils, and apply this knowledge in the practice of physical education. When applying a differentiated approach to physical education classes and the formation of school pupil's groups (teams), it is important to take into account the degree of effectiveness of joint work of pupils 
with different types of temperament, which will contribute to the successful complex development of various physical qualities. The task of the teacher is to promote development of the positive aspects of different psychodynamic properties using a systematic educational work. Correction of the psychodynamic properties of schoolchildren is necessary so that the requirements for the physical development of each individual school pupil correspond to his psychodynamic properties and type of temperament, re-educate the negative traits of certain properties and nurture positive traits, develop the pupil as an individual and optimize the physical education process. Such corrective work should be carried out mainly in the direction of the development of activity and vigor, mobility and motor abilities, the integrated development of motor skills.

Key words: nervous system, psychodynamic properties, temperament, school pupils, physical training, differentiated approach, individual approach.

\section{Анотація}

Вступ. Кожна людина від народження є унікальною особистістю, яка актуалізує проблему поваги до особистості кожного школяра, іiї різноманітних проявів, використання у процесі виховання диференційованого та індивідуального підходів. Значною мірою особистість школяра проявляється через її психодинамічні властивості, і насамперед - властивості темпераменту, від яких залежать швидкість та інтенсивність перебігу психічних процесів, темп і ритм діяльності, ії оцінка і самоконтроль. Актуальність урахування психодинамічних властивостей у фізичному вихованні школярів пов'язана 3 тим, що таке врахування дасть змогу оптимізувати педагогічну роботу на заняттях з фізичної культури, впроваджувати у процес фізичного виховання диференційований та індивідуальний підходи. На сьогодні практично не вивчено вплив психодинамічних властивостей школярів на можливості їх фізичного розвитку, не розроблено педагогічні засоби корекції проявів цих властивостей у процесі фізичного виховання.

Мета дослідження: на основі вивчення літературних джерел визначити психодинамічні властивості дітей і підлітків шкільного віку, охарактеризувати теоретико-методичні проблеми та розробити відповідні засади їх фізичного виховання з урахуванням цих властивостей, а також методи й засоби їх корекції задля нівелювання негативних і стимулювання позитивних рис окремих типів темпераменту школярів.

Матеріал і методи: аналіз та узагальнення літературних джерел.

Результати. У статті проаналізовано основні психодинамічні властивості людини - темперамент, сенситивність і динамічні аспекти поведінки, при цьому основна увага акцентується на проявах властивостей темпераменту. Підкреслюється, що в дітей є характерні особливості прояву психодинамічних властивостей, зокрема темпераменту, які залежать від властивостей нервової системи. Розглядаються зв'язки між психічними та психодинамічними властивостями школярів. Стверджується, що такі фізичні якості учнів, як швидкість, витривалість і сила залежать, крім іншого, від типу темпераменту. Розкрито важливі аспекти педагогічної роботи зі школярами з різними психодинамічними властивостями. Показано, що вирішення конкретних педагогічних завдань на заняттях з фізичної культури повинно бути узгоджене із психодинамічними властивостями учнів, які в процесі фізичного виховання найбільш яскраво проявляються у спільній діяльності. Наведено оптимальні варіанти сумісності різних властивостей темпераменту школярів. Розроблено критерії врахування психодинамічних властивостей учнів при розвитку різних фізичних якостей, відповідні засоби педагогічного впливу на дітей і підлітків з різними типами темпераменту. Запропоновано методи й засоби корекції психодинамічних властивостей школярів на заняттях з фізичної культури.

Висновки. Вчитель фізичної культури повинен володіти знаннями про зв'язки між конкретними психодинамічними властивостями та різними особистісними якостями, характеристиками, здібностями учнів $\mathrm{i}$ застосовувати ці знання у практиці фізичного виховання. При застосуванні на заняттях з фізичної культури диференційованого підходу та формуванні груп (команд) школярів важливо враховувати ступінь ефективності спільної роботи учнів з різними типами темпераменту, що сприятиме успішному комплексному розвитку різних фізичних якостей. Завданням учителя $є$ : сприяти розвитку позитивних сторін різних психодинамічних властивостей через систематичну виховну роботу. Діяльність щодо корекції психодинамічних властивостей учнів зумовлена необхідністю досягнення відповідності вимог до фізичного розвитку кожного окремого школяра його психодинамічним властивостям і типу темпераменту, нівелювання негативних рис певних властивостей і виховання рис позитивних, розвитку його як особистості та оптимізації процесу його фізичного виховання. Така корекційна робота повинна здійснюватися переважно в напрямку розвитку активності та енергійності, рухливості і моторних здібностей, комплексного розвитку рухових якостей.

Ключові слова: нервова система, психодинамічні властивості, темперамент, школярі, фізичне виховання, диференційований підхід, індивідуальний підхід. 
Введение. Каждый человек от рождения является уникальной личностью, что актуализирует проблему уважения личности каждого школьника, ее разнообразных проявлений, использования в процессе воспитания дифференцированного и индивидуального подходов. В значительной степени личность школьника проявляется в ее психодинамических свойствах, и прежде всего, - свойствах темперамента, от которых зависят быстрота и интенсивность протекания психических процессов, темп и ритм деятельности, ее оценка и самоконтроль. Актуальность учета психодинамических свойств в физическом воспитании школьников связана с тем, что такой учет даст возможность оптимизировать педагогическую работу на занятиях по физической культуре, внедрять в процесс физического воспитания дифференцированный и индивидуальный подходы. На сегодняшний день практически не изучено влияние психодинамических свойств школьников на возможности их физического развития, не разработаны педагогические средства коррекции проявлений этих свойств в процессе физического воспитания.

Цель исследования: на основе изучения литературных источников определить психодинамические свойства детей и подростков школьного возраста, охарактеризовать теоретико-методические проблемы и разработать соответствующие основы их физического воспитания с учетом этих свойств, а также методы и средства их коррекции для нивелирования отрицательных и стимулирования положительных черт отдельных типов темперамента школьников.

Материал и методы: анализ и обобщение литературных источников.

Результаты. В статье проанализированы основные психодинамические свойства человека - темперамент, сенситивность и динамические аспекты поведения, при этом основное внимание акцентируется на проявлениях свойств темперамента. Подчеркивается, что детям свойственны характерные особенности проявления психодинамических свойств, в частности темперамента, зависящие от свойств нервной системы. Рассматриваются связи между психическими и психодинамическими свойствами школьников. Утверждается, что такие физические качества учеников, как быстрота, выносливость и сила, зависят, кроме прочего, от типа темперамента. Раскрыты важные аспекты педагогической работы со школьниками с различными психодинамическими свойствами. Показано, что решение конкретных педагогических задач на занятиях по физической культуре должно быть согласовано с психодинамическими свойствами учеников, которые в процессе физического воспитания особенно ярко проявляются в совместной деятельности. Приведены оптимальные варианты совместимости различных свойств темперамента школьников. Разработаны критерии учета психодинамических свойств учеников при развитии различных физических качеств, соответствующие средства педагогического влияния на детей и подростков с разными типами темперамента. Предложены методы и средства коррекции психодинамических свойств школьников на занятиях по физической культуре.

Выводы. Учитель физической культуры должен владеть знаниями о связях между конкретными психодинамическими свойствами и различными личностными качествами, характеристиками, способностями учеников и применять эти знания в практике физического воспитания. При применении на занятиях по физической культуре дифференцированного подхода и формировании групп (команд) школьников важно учитывать степень эффективности совместной работы учеников с разными типами темперамента, что будет способствовать успешному комплексному развитию различных физических качеств. Задача учителя - способствовать развитию положительных сторон разных психодинамических свойств с помощью систематической воспитательной работы. Деятельность по коррекции психодинамических свойств учеников обусловлена необходимостью достижения соответствия требований к физическому развитию каждого отдельного школьника его психодинамическим свойствам и типу темперамента, нивелирования отрицательных черт определенных свойств и воспитания черт положительных, развития его как личности и оптимизации процесса его физического воспитания. Такая коррекционная работа должна осуществляться преимущественно в направлении развития активности и энергичности, подвижности и двигательных способностей, комплексного развития двигательных качеств.

Ключевые слова: нервная система, психодинамические свойства, темперамент, школьники, физическое воспитание, дифференцированный подход, индивидуальный подход.

Вступ. Здавна відомо, що люди суттєво відрізняються один від одного своєю поведінкою, порізному виражають свої почуття, неоднаково реагують на аналогічні подразники зовнішнього

(C) Бондарчук Н., Чернов В., Kalabiska I., 2019 середовища. Все це вказує на те, що кожна людина від народження $є$ унікальною особистістю, i це важливо враховувати у процесі шкільного виховання, 3 повагою ставитися до особистості кожного школяра, застосовуючи диференційований та індивідуальний підходи. Вже давно доведено, що відмінності між людьми як особистостями неможливо пояснити тільки факторами зовніш- 
ніх впливів чи конституційними властивостями людини; отже, ми повинні звернутися до психодинамічних властивостей, від яких значною мірою залежать швидкість виникнення та перебігу психічних процесів (мислення, сприймання й т. д.), їхня інтенсивність (активність волі, сила емоцій тощо), темп і ритм діяльності, iї оцінка і самоконтроль.

Прояви психодинамічних властивостей і зокрема темпераменту людини становили значний дослідницький інтерес 3 давніхдавен: цими питаннями цікавився Гіппократ, останніми сторіччями їх вивчали 3. Фрейд, К. Юнг та багато інших вчених. В історії розвитку вчення про темперамент визначальними вважалися різні властивості: у традиції німецького фізіолога і психолога В. Вундта - швидкість і сила емоційних реакцій; американського психолога Р. Даймонд - рівень активності і переважний чуттєвий тон; англійського психолога Г. Айзенка - екстраверсія / інтроверсія та емоційна стійкість; польського психолога Я.Стреляу - реактивність та активність. Російський дослідник I. Павлов вивчав феномен людського темпераменту на базі психофізіології, розробивши при цьому найбільш уживану його типологію. Заслуговує на увагу концепція інтегральної індивідуальності іншого російського вченого В. Мерліна, яка будується на врахуванні зв'язків властивостей нервової системи i темпераменту.

Слід звернути увагу на сучасні наукові розвідки, автори яких досліджують проблеми індивідуальних відмінностей людей на рівні психодинаміки, прояви психодинамічних властивостей особистості в поведінці та міжособистісних стосунках (Батаршев, 2000; Дудин, 1994; Кашапов, 2002; Мерлин, 2009). Важливим напрямом наукових пошуків є дослідження місця психодинамічних властивостей в особистісній структурі людини, зв'язків між темпераментом і характером (Борисов, 2016; Обозов, 1998; Юров, 2013). В контексті даної наукової розвідки особливий інтерес представляють дослідження різних проявів психодинамічних властивостей у дитячому, підлітковому, юнацькому віці. Так, М. Прокоф'єва досліджує можливості застосування диференційованого підходу при навчанні школярів з урахуванням типів їхнього темпераменту (Прокоф'єва, 2012). Є. Биков та співавтори вивчають зв'язок психодинамических функций з різними проявами розумової діяльності хлопців і дівчат (Быков, Мекешин, Казакова, 2009). I. Дубровіна та співавтори розробляють систему корекційнорозвиваючої роботи молодших школярів, зокрема $з$ урахуванням проявів їхнього темпераменту (Дубровина, Андреева, Данилова, 1998). Окрему наукову розвідку присвячено питанням корекції негативних проявів різних типів темпераменту молодших школярів у ході шкільного навчання (Олійник, Бегас, 2017). Досліджень, присвячених проблематиці врахування психодинамічних властивостей дітей і підлітків у процесі їх фізичного виховання, обмаль. Варто відзначити спроби визначення взаємозв'язків між темпераментом і фізичною активністю в різних вікових періодах дитинства та підліткового віку. Розглядаються напрями застосування диференційованого підходу на фізкультурних заняттях зі старшокласниками $з$ орієнтацією на різні типи темпераменту (Кан, 2014). Започатковане вивчення можливостей урахування різних проявів психодинамічних властивостей на заняттях 3 фізичної культури, а також їх корекції в широкому контексті вдосконалення методів і засобів педагогічної роботи у процесі фізичного виховання дітей і підлітків, більш активного впровадження у процес шкільного фізичного ви- ховання диференційованого та індивідуального підходів, загальної оптимізації навчально-виховного процесу в загальноосвітніх навчальних закладах (Бондарчук, Чернов, 2019).

Гіпотеза дослідження: врахування психодинамічних властивостей дітей і підлітків шкільного віку, використання різних методів і засобів їх корекції в рамках систематичної виховної роботи на заняттях 3 фізичної культури сприятимуть розвитку позитивних рис різних психодинамічних властивостей школярів, досягненню відповідності вимог до фізичного розвитку кожного окремого школяра його психодинамічним властивостям і типу темпераменту, розвитку кожного учня як особистості та загальній оптимізації процесу його фізичного виховання.

Мета дослідження - на основі вивчення літературних джерел визначити психодинамічні властивості дітей і підлітків шкільного віку, охарактеризувати теоретико-методичні проблеми та розробити відповідні засади їх фізичного виховання з урахуванням цих властивостей, а також методи й засоби їх корекції задля нівелювання негативних і стимулювання позитивних рис окремих типів темпераменту школярів.

Матеріал і методи дослідження. При підготовці статті було застосовано аналіз та узагальнення літературних джерел, які дозволяють отримати повне уявлення про стан досліджуваних проблем, накопичений досвід їх вирішення.

Результати дослідження. Психодинамічний рівень індивіда представляє собою стійку єдність його різних психодинамічних властивостей, а центральним утворенням у структурі цих властивостей є темперамент, який визначає формально-динамічний, процесуальний аспект людської психіки; крім того, виділяють також сенситивність і динамічні

(c) Бондарчук Н., Чернов В., Kalabiska I., 2019 
аспекти поведінки. Темперамент людини проявляється в різних сферах: у сфері загальної активності він визначається ступенем інтенсивності взаємодії людини 3 природним і соціальним середовищем; у сфері моторної активності - виражається у швидкості рухів, темпі мовлення, зовнішній рухливості тощо; в емоційній сфеpi - у швидкості змін емоційних станів, ступеня сприйнятливості емоційних впливів. Важливими властивостями темпераменту $\epsilon$ загальна психічна активність і реактивність, руховий (моторний) компонент, емоційність (зокрема емоційна вразливість, імпульсивність, емоційна лабільність), екстраверсія або інтроверсія, темп перебігу реакцій, пластичність i ригідність. Дослідження проявів психодинамічних властивостей людини повинно спиратися на певну типологію темпераменту. Наприклад, у рамках описової теорії темпераменту нідерландських психологів Г. Хейманса та Е. Вірсми виділено такі біполярні характеристики темпераменту: емоційність або ііі відсутність; активність або пасивність; первинність або вторинність реакцій на стимули оточуючого середовища. В результаті комбінування цих характеристик учені виділили вісім типів темпераменту: нервовий; сентиментальний; дуже діяльний; пристрасний; сангвінік; флегматик; аморфний (безтурботний); апатичний. Більш традиційною для диференційної психології вважається класифікація, заснована на функціональній типології вищої нервової діяльності І. Павлова. В їі рамках люди поділяються на сангвініків, холериків, флегматиків і меланхоліків.

Сенситивність - як одна із психодинамічних властивостей - визначає, на думку В. Мерліна, найменшу силу зовнішніх впливів, необхідну для виникнення будь-якої психічної реакції людини (Мерлин, 2009). Психологи визначають іiі як загальну влас- тивість сенсорної організації, загальний спосіб чутливості, хоча результати практичних досліджень свідчать про відносну незалежність чутливості окремих аналізаторів (зорового, слухового тощо). Динамічні аспекти поведінки зумовлені своєрідним поєднанням активності, що визначається інтенсивністю, та обсягами взаємодії людини $з$ навколишнім середовищем (фізичним і соціальним), і ступенем вираженості емоційних реакцій.

Хоча властивості темпераменту є вродженими, спадково обумовленими, як i ті властивості нервової системи, що становлять їхню фізіологічну основу, це не означає, що різні типи темпераменту мають однакові прояви в різному віці; для різних вікових періодів характерні свої особливості таких проявів. У дитячому і підлітковому віці вони значною мірою залежать від дозрівання i розвитку організму, мозкових основ психіки, властивостей нервової системи. Учні із сильною нервовою системою частіше бадьорі, більшою мірою впевнені в собі, з більшою легкістю засвоюють учбовий матеріал (навіть, значний за обсягом). Вони більш енергійні, рідше бувають розслабленими та стомленими, більш ефективно використовують свій час, адже протягом однакового часу виконують більше учбової роботи. 3 іншого боку, їм важче дається робота, яка вимагає впорядкування матеріалу, систематизації, планування своєї діяльності, перевірки iii результатів. Учні зі слабкою нервовою системою, зі свого боку, більш спокійні та слухняні, схильні до акуратності. Вони більш чутливі й частіше стомлюються, частково, - через те що більшою мірою напружуються при навчанні. У складних ситуаціях такі діти частіше втрачають самовладання, що може позначатися на їхній реакції на дії вчителя. Отже, в залежності від віку, а також від типу нервової системи діти можуть мати свою індивідуальну специфіку активності, емоційності, моторики. Через це в них можуть специфічно проявлятися властивості певних типів темпераменту.

Особистість школяра - це складна система зі своїми індивідуальними особливостями, що відрізняють одну дитину від іншої. В ній можуть бути виділені декілька рівнів: індивідуальні властивості організму (біохімічні, соматичні, нейродинамічні); психічні та психодинамічні властивості особистості; соціально-психологічні індивідуальні властивості. Між психічними та психодинамічними властивостями школяра існують однорівневі та різнорівневі зв'язки. Холерики найчастіше екстраверти 3 низьким рівнем психічної стійкості, високою збудженістю, підвищеною експресією, значним рівнем пластичності; сангвініки - екстраверти 3 високим рівнем психічної стійкості, помірною збудженістю, помірною експресією, достатньо пластичні; флегматики - інтроверти 3 дуже високим рівнем психічної стійкості, низькою збудженістю, зниженою експресією, значним рівнем ригідності; меланхоліки - інтроверти 3 дуже низьким рівнем психічної стійкості, високою збудженістю, підвищеною експресією, достатньо ригідні.

Як засвідчують результати педагогічного спостереження та візуальної психодіагностики, зв'язки між типами темпераменту та рівнем фізичного розвитку i фізичної підготовленості школярів проявляються насамперед у залежності розвитку окремих фізичних якостей від того чи іншого типу темпераменту. В першу чергу йдеться про такі фізичні якості, як швидкість, витривалість і сила. Більшою швидкістю володіють. як правило, сангвініки та холерики. Більшості меланхоліків властивий середній рівень розвитку швидкості, а у флегматиків швидкість розвинена найслабше 
порівняно з іншими типами темпераменту. По-іншому проявляється в дітей 3 різними типами темпераменту розвиток витривалості. Найбільшу витривалість здебільшого демонструють учні 3 флегматичним типом темпераменту. Сангвінікам притаманний середній рівень розвитку витривалості, а холерики та особливо меланхоліки характеризуються слабкою витривалістю. Більшою силою, зі свого боку, володіють, як правило, холерики та меланхоліки; для флегматиків властивий середній рівень розвитку силових якостей, а у сангвініків сила розвинена меншою мірою

Вважаємо, що при організації процесу шкільного фізичного виховання та проведенні занять iз фізичної культури в загальноосвітніх навчальних закладах повинні бути враховані зв'язки конкретних психодинамічних властивостей 3 різними особистісними якостями, властивостями, здібностями, що найбільш яскраво проявляються у спільній діяльності, яка нерідко вимагає узгодження не тільки змістових, а й формально-динамічних характеристик поведінки учнів. Також потрібно брати до уваги сумісність школярів із різними проявами психодинамічних властивостей, щоб у спільній навчальній діяльності ці властивості доповнювали одна одну. Сангвініки при спільній навчальній діяльності, як показують результати дослідження, ефективніше працюють із меланхоліками або холериками, але якщо їх партнерами є флегматики або також сангвініки, показники ефективності спільної діяльності порівняно 3 індивідуальною зменшуються. Відповідно, з точки зору ефективності такої діяльності холерикам краще працювати 3 флегматиками та меланхоліками, гірше - із сангвініками, і абсолютно неефективно - 3 холериками. Меланхоліки краще працюють тоді, коли їх партнерами є сангвініки або хо- лерики; натомість ефективність знижується, якщо в якості партнерів опиняються флегматики та особливо меланхоліки. Зрештою, для флегматиків найкращим варіантом є діяльність разом із флегматиками або холериками; менш ефективною виявляється діяльність із меланхоліками чи сангвініками. Показово, що при спільній діяльності лише один тип темпераменту - флегматичний - покращує показники ефективності при взаємодії з партнерами, які мають подібну структуру психодинамічних властивостей і тип темпераменту. Загалом можемо виділили три найбільш оптимальні варіанти сполучуваності властивостей темпераменту (в парах), здатні впливати на індивідуальний стиль спільної діяльності: 1) сангвінік (екстраверт, стабільний) - меланхолік (інтроверт, лабільний); 2) холерик (екстраверт, лабільний) - флегматик (інтроверт, стабільний); 3) флегматик - флегматик. Якщо говорити про роль школярів із різними типами темпераменту в учнівському колективі (групі, команді), слід зауважити, що меланхоліки найменшою мірою підходять на роль лідера групи (капітана команди), адже цьому не сприяють особливості їхньої нервової системи. Сангвініки, навпаки, маючи значні енергетичні резерви, здатні вести за собою партнерів і тому якнайкраще відповідають вимогам до лідерської ролі. Холерики найкраще проявляють себе в ситуаціях, що потребують швидкої реакції, а флегматики - в ситуаціях, що потребують спокійних, виважених рішень (Борисов, 2016).

Ці дані рекомендуємо використовувати на шкільних та позашкільних заняттях 3 фізичної культури при застосуванні групового методу організації учнів. Щоб досягти більш успішного засвоєння навчального матеріалу, кращого фізичного розвитку та підвищення рівня фізичної підготовленості вчитель фізичної куль- тури може організовувати учнів у пари, трійки та групи (для виконання вправ, участі в естафетах, рухливих іграх тощо) з урахуванням їхніх типів темпераменту. Отже, психодинамічні властивості й типи темпераменту повинні виступати важливими критеріями диференційованого підходу до фізичного виховання школярів.

Окремої уваги заслуговують рекомендації щодо врахування типів темпераменту школярів при розвитку їхніх фізичних якостей. При розвитку силових якостей, - як показують результати педагогічних спостережень, - перевагу мають діти й підлітки холеричного та меланхолічного типів темпераменту. У флегматиків потенціал розвитку сили дещо менший, у сангвініків - ще менший. Застосування методу максимальних зусиль при розвитку сили пов'язане зі значними психічними напруженнями, тому рекомендується віддавати перевагу методу неграничних зусиль із граничним числом повторів вправ, але при цьому враховувати, що цей метод може знижувати мотивацію сангвініків і меланхоліків, які важче переносять одноманітну роботу. Для розвитку швидкості більший потенціал мають холерики і сангвініки, менший - меланхоліки, ще менший - флегматики. При виконанні завдань розвитку частоти i швидкості рухів рекомендуємо застосовувати повторний, повторно-прогресуючий і перемінний методи тренування. Розвиток витривалості значною мірою пов'язаний із розвитком біохімічних процесів і залежить від стійкості нервової системи (передусім мається на увазі стійкість до збудження значної інтенсивності). Найбільш високою витривалістю володіють здебільшого флегматики, у сангвініків, як правило, спостерігається середній рівень розвитку витривалості, меншою мірою витривалість розвинена у холериків і меланхоліків. Щодо розвитку гнучкості і спритності,

(c) Бондарчук Н., Чернов В., Kalabiska I., 2019 
особливості розвитку цих фізичних якостей у школярів з різними психодинамічними властивостями встановити важче, хоча $є$ підстави припустити, що в розвитку спритності перевагу можуть мати учні сангвінічного та холеричного типу, а в меланхоліків та флегматиків рівень іiі розвитку середній або низький.

Вчителю фізичної культури необхідно вирішити питання: в які способи впливати на учнів 3 різними психодинамічними властивостями і типами темпераменту, щоб максимально ефективно розвивати їхні фізичні якості. Практикою доведено, що найбільш проблемними в цьому плані $€$ діти 3 холеричним і меланхолічним типами темпераменту. При роботі з холериками постає найпершезавдання послаблювати гальмівні психічні процеси. Від таких учнів необхідно постійно, у м'якій формі вимагати спокійних, обміркованих дій, стриманості в поведінці (особливо, - при стосунках з однолітками), акуратності й порядку в навчанні. Холерики вимагають при роботі з ними м'якої форми контактів, що допоможе уникнути симулювання зайвого збудження, через яке школярі 3 холеричним типом темпераменту можуть втратити контроль за своєю поведінкою. Такі учні нерідко виявляють нестриманість, непосидючість, навіть агресивність. Слід брати до уваги, що вирішення цікавих навчальних завдань може сприяти формуванню в них наполегливості, сумлінності, ретельності і точності в навчальній роботі. Також м'якими, тактовними, чуйними повинні бути контакти 3 меланхоліками, оскільки підвищені вимоги та зайва суворість можуть їх ще більше загальмувати. Одним із основних завдань при роботі 3 ними $є$ сприяння налагодженню тісних продуктивних контактів із однолітками, повноцінному "входженню в колектив" класу, групи й т.д. Але при застосуванні дифе- ренційованого підходу на заняттях з фізичної культури слід обережно ставитися до формування груп, до складу яких входять діти 3 меланхолічним типом темпераменту. Сприяючи "входженню в колектив", одночасно потрібно пильно стежити за тим, щоб діти відчували себе захищеними. Школярі 3 меланхолічним типом темпераменту потребують штучного стимулювання їх активності, яке повинно відбуватися у спокійній обстановці. Для таких учнів корисно організовувати штучні ситуації успіху, пропонувати цікаві творчі завдання, розв'язання яких сприятиме підвищенню віри у власні сили, у здатність долати труднощі. Працюючи з учнямисангвініками, рекомендується приділяти особливу увагу вихованню посидючості, цілеспрямованості, наполегливості. У флегматиків рекомендуємо розвивати активність і рухливість, але так, щоб не втрачався інтерес до того, що вони звикли робити; в іншому разі байдужість може розповсюдитися на всі види діяльності.

Вважаємо, що врахування психодинамічних властивостей школярів на заняттях 3 фізичної культури може мати важливі позитивні наслідки в плані оптимізації процесу фізичного виховання. В учнів зі слабкими типами нервової системи може поступово розвиватися сильна воля. Цікавими можуть бути результати педагогічної роботи із сильними типами, адже не кожен холерик характеризується рішучістю, а сангвінік - чуйністю. Ці якості можуть бути розвинені за допомогою педагогічних впливів. Звертаємо також увагу на розвиток у школярів саморегуляції, здатності до самовиховання. Слід враховувати, що, наприклад, холерику порівняно 3 флегматиком легше виховати в собі швидкість та енергійність дій, а флегматику порівняно з холериком - витримку. Отже, для різних психодинамічних властивостей і типів темпераменту потрібно застосовувати різ- ні педагогічні прийоми. Але слід пам'ятати, що завдання вчителя полягає не в тому, щоб переробити один тип темпераменту на інший, а в тому, щоб через систематичну виховну роботу сприяти розвитку позитивних сторін різних психодинамічних властивостей, коригувати негативні риси, властиві тому чи іншому типу.

Крім урахування проявів різних психодинамічних властивостей у процесі фізичного виховання школярів, вважаємо розумним та обгрунтованим вжиття заходів щодо корекції цих проявів. Це пов'язано з тим, що вони можуть сприйматися як позитивно, так i негативно, а цілеспрямована корекційна робота сприятиме нівелюванню негативних рис певних психодинамічних властивостей i розвитку позитивних. Заходи щодо корекції психодинамічних проявів учнів сприятимуть більш повному прояву їхніх особистісних якостей і здібностей, позитивних сторін різних типів темпераменту. Зокрема, вони дадуть можливість проявитися: меланхоліку - як емоційній людині, яка здатна глибоко переживати; флегматику - як людині стриманій, яка завжди приймає вивірені, правильні рішення; сангвініку як людині глибоко чуйній до оточуючих і до своєї роботи; холерику - як людині пристрасній та активній у будь-якій справі.

Для окремих учнів такі заходи сприятимуть розвитку активності та енергійності. Для забезпечення розвитку пропонуємо дотримуватися таких методичних рекомендацій: 1) при постановці несподіваних завдань і вимог до учнів вимагати швидкого рішення або відповіді, але залежно від типу темпераменту надавати необхідний час на обмірковування або підготовку; 2) під час виконання завдань давати час на перевірку власних дій (відповідей) і виправлення помилок, але обмежувати цей час залежно від типу темпераменту; 3) вимагати швидких 
відповідей або дій згідно 3 новим учбовим матеріалом, але на наступному занятті повторювати опитування (виконання вправ) i сприяти тому, щоб учні самі усвідомлювали свої помилки; 4) через правильну тактику постановки навчальних завдань та заохочень формувати в учнів упевненість у своїх силах, у реальних можливостях підвищення рівня своєї фізичної підготовленості; 5) забезпечувати мінімальні відволікання учнів від виконання навчальних завдань. Для дітей і підлітків із сильною нервовою системою пропонуються додаткові рекомендації: 1) постійно забезпечувати часту зміну фізичних вправ (різних за змістом та інтенсивністю), щоб максимально уникати монотонності в навчальній роботі; 2) застосовувати педагогічні прийоми, спрямовані на тренування навичок самоконтролю; 3) при групових методах тренування давати таким школярам лідерські ролі.

Для забезпечення розвитку рухливості та моторних здібностей учителю необхідно звертати увагу на такі можливі навчальні ситуації: 1) різноманітні за змістом і способами розв'язання завдання; 2) ситуації, що вимагають високого темпу навчальної діяльності; 3) ситуації, що вимагають швидкого переключення уваги; 4) ситуації iз жорстким обмеженням часу на виконання навчального завдання; 5) одночасне засвоєння нового i повторення старого навчального матеріалу. Розвиток рухливості та моторних здібностей в інертних учнів вимагає дотримання таких правил: 1) не вимагати від дітей миттєвого включення в роботу i забезпечити поступове зростання активності; 2) пам'ятати, що активність діяльності залежить від змісту навчального завдання; 3) в разі припущення помилок при виконанні вправ не вимагати їх миттєвого виправлення, а дати час на обмірковування причин; 4) включати в заняття вправи $з$ елементами імпровізації, але брати до уваги складність їх виконання учнями; 5) на початку заняття давати невеликі навантаження (враховуючи, що такі діти важко відволікаються від попередніх навчальних ситуацій), але в наступні хвилини забезпечувати все більше їх зростання; 6) стежити за тим, щоб учні не відволікалися ні на що в момент виконання вправ. При роботі 3 рухливими школярами необхідно дотримуватися такої тактики: 1) збільшення обсягів нового матеріалу частинами 3 періодичними скороченнями обсягів навчальної роботи; 2) урізноманітнення змісту навчальних завдань і вправ; 3) забезпечення частих переходів від одного виду вправ до іншого; 4) надання переваги перед іншими школярами при включенні в навчальну роботу.

Для екстравертів та інтровертів рекомендуємо пропонувати різні навчальні ролі. Так, для учнів-екстравертів підходять ролі, що дозволяють забезпечити комфортні умови для формування рухових навичок. Потрібна часта зміна ролей, які вимагають однакових рухових характеристик (це підтримує інтерес до навчальної діяльності). 3 іншого боку, в окремих випадках доцільно закріплювати за учнями однотипні ролі, що дозволяє формувати міцні та гнучкі рухові навички. Для таких школярів підходять також ролі, що дозволяють за необхідності коригувати негативні прояви індивідуальних характеристик при контактах 3 однолітками (мається на увазі насамперед стремління до домінування). Від учителя вимагається балансувати на заняттях розподіл ролей, при виконанні яких одні учні командують іншими або повинні відкрито виражати прохання, свою згоду чи незгоду. Другі допомагають дітям подивитися на себе зі сторони, краще зрозуміти своїх товаришів. Для учнів-інтровертів бажано створювати ролі, що забезпечують комфортні умови для формування рухових та інших навичок.
Такі ролі не мають бути ззовні складними й повинні викликати до них позитивне ставлення. Прийнятними для інтровертів $є$ також ролі, що дозволяють за необхідності коригувати негативні прояви індивідуальних характеристик при контактах з однолітками.

Коли вимоги вчителя відповідають психодинамічним властивостям конкретного школяра, забезпечуються кращі умови для реалізації навчального потенціалу і творчих здібностей школярів незалежно від належності до певної вікової категорії. Якщо ж такої відповідності немає, наслідками можуть бути гальмування розвитку рухових якостей і здібностей, відхилення від нормального психофізичного розвитку учнів.

Обговорення результатів. Це дослідження відкриває новий напрям вивчення особливостей прояву психодинамічних властивостей дітей і підлітків шкільного віку i, відповідно, започатковує нові педагогічні засоби фізичного виховання школярів. Проведена нами теоретична розвідка загалом підтверджує висновки, зроблені різними дослідниками щодо проявів у школярів різних психодинамічних властивостей і властивостей різних типів темпераменту зокрема, зв'язку цих властивостей із проявами розумової діяльності та фізичної активності. Врахування психодинамічних властивостей школярів у процесі їх фізичного виховання покликане доповнити вже розроблені засоби застосування диференційованого та індивідуального підходів до фізичного виховання школярів. Так само розширюються і доповнюються засоби відповідної корекційно-розвиваючої роботи. Результати проведеного дослідження поглиблюють теоретико-методичні розробки нових напрямів фізичного виховання школярів з урахуванням їхніх психодинамічних властивостей. Висловлюємо припущення, згідно $з$ яким застосування наведених

(C) Бондарчук Н., Чернов В., Kalabiska I., 2019 
рекомендацій сприятиме підвищенню рівня фізичної підготовленості дітей і підлітків, розвитку їхніх фізичних якостей i моторних здібностей. Навіть незначні зміни у бік покращення проявів психодинамічних властивостей (ініціативність, активність, моторні характеристики тощо) можуть свідчити про зростання ефективності навчальної діяльності. Застосування диференційованого підходу забезпечить компенсацію психодинамічних властивостей партнерів із різними типами темпераменту при спільному виконанні навчальних завдань у групах (командах), що загалом підвищить загальну результативність групового методу тренування на заняттях.

Висновки. Між психічними та психодинамічними властивостями школярів існують тісні зв'язки, що позначають вплив типу темпераменту на екстравертивність, стійкість, збудженість, експресію. Зв'язки між типами темпераменту та рівнем фізичного розвитку учнів проявляються в залежності розвитку окремих фізичних якостей (насамперед швидкості, витривалості, сили) від того чи іншого типу темпераменту. Організація процесу фізичного виховання школярів, вирішення конкретних педагогічних завдань на заняттях $з$ фізичної культури повинні бути узгоджені із психодинамічними властивостями учнів. При роботі, диференційованій за параметрами психодинамічних властивостей, завдання вчителя полягає не в тому, щоб переробити один тип темпераменту на інший, а в тому, щоб через систематичну виховну роботу сприяти розвитку позитивних сторін різних властивостей. Вчитель фізичної культури повинен володіти знаннями про зв'язки між конкретними психодинамічними властивостями та різними особистісними якостями, характеристиками, здібностями учнів, і застосовувати ці знання у практиці фізичного виховання. Завданням учителя є сприяти розвитку позитивних сторін різних психодинамічних властивостей через систематичну виховну роботу. Діяльність щодо корекції психодинамічних властивостей учнів зумовлена необхідністю досягнення відповідності вимог до фізичного розвитку кожного окремого школяра його психодинамічним властивостям і типу темпераменту, нівелювання негативних рис певних властивостей і виховання рис позитивних, розвитку його як особистості та оптимізації процесу його фізичного виховання. Така корекційна робота повинна здійснюватися переважно в напрямку розвитку активності та енергійності, рухливості і моторних здібностей, комплексного розвитку рухових якостей.

Конфлікт інтересів: автори заявляють, що конфлікту інтересів не існує.

Перспективи подальших досліджень. Подальші дослідження психодинамічних властивостей дітей і підлітків шкільного віку будуть пов'язані з вивченням їх впливу на фізичний розвиток школярів окремих вікових категорій. Основою такого вивчення повинно стати дослідження взаємозв'язку типів темпераменту школярів різних вікових категорій та особливостей фізичного розвитку, зокрема розвитку фізичних якостей. Дослідження буде проведене в рамках педагогіки, теорії і методики фізичного виховання в загальноосвітньому навчальному закладі.

\section{Література}

1. Батаршев А.В. Психология индивидуальных различий Москва: Гуманитарный издательский центр ВЛАДОС, 2000. 306 с.

2. Бондарчук Н.Я., Чернов В.Д. Теоретико-методичні аспекти фізичного виховання школярів 3 урахуванням їхніх психодинамічних властивостей. Науковий вісник Ужгородського університету. Серія: Педагогіка. Соціальна робота. 2019. Вип. 1 (44). С. 13-17.

3. Борисов Д.Д. Темперамент и индивидуальность. Исследование темперамента методом визуальной психодиагностики. Проблемы современного образования. 2016. № 5. С. 134-141.

4. Быков Е.В., Мекешкин Е.А., Казакова О.А., Чипышев А.В., Рязанцев А.В. Развитие психодинамических функций у учащихся младших классов с различным уровнем умственных нагрузок. Вестник ЮУрГУ. Серия: Образование, здравоохранение, физическая культура. 2009.

\section{References}

1. Batarshev, A.V. (2000). Psihologiya individual'nyh razlichij. [Psychology of individual differences]. Moskva: Gumanitarnyj izdatel'skij centr VLADOS, 306 (in Russian).

2. Bondarchuk, N.Ya., \& Chernov, V.D. (2019). Teoretyko-metodychni aspekty fizychnoho vykhovannia shkoliariv z urakhuvanniam yikhnikh psykhodynamichnykh vlastyvostei. [Theoretical and methodological aspects of physical training of school pupils taking into account their psychodynamic properties]. Scientific Herald of Uzhhorod University. Series: Pedagogy. Social Work, 1 (44). 13-17 (in Ukrainian).

3. Borisov, D.D. (2016). Temperament i individual'nost'. Issledovanie temperamenta metodom vizual'noj psihodiagnostiki. [Temperament and personality. The study of temperament by the method of visual psychodiagnostics]. Problems of modern education, 5, 134-141 (in Russian).

4. Bykov, E.V., \& Mekeshkin, E.A., \& Kazakova, 
Вып. 21. № 39 (172). С. 19-23.

5. Дубровина И.В., Андреева А.Д., Данилова Е.Е., Вохмянина Т.В. Психокоррекционная и развивающая работа с детьми. Москва: Издательский центр «Академия», 1998. 160 с.

6. Дудин С.И. О связи темперамента с общими способностями. Психологический журнал. 1994. Т. 15. № 2. С. 165-170.

7. Кан Ю.Б. Дослідження рівня фізичної підготовленості учнів з різними психодинамічними властивостями. Науковий часопис Національного педагогічного університету ім. М. Драгоманова. Серія 15: Науково-педагогічні проблеми фізичної культури / За ред. Г.М. Арзютова. Вип. 3 К (44). Київ : Вид-во НПУ ім. М. Драгоманова, 2014. С. 298-303.

8. Кашапов Р.Р. Типология личности, или какие мы разные. Москва: АСТ-ПРЕСС КНИГА, 2002. $320 \mathrm{c}$.

9. Кібальник О.Я. Шляхи покращення фізичної підготовленості учнів підліткового віку. Слобожанський науково-спортивний вісник. Харків: ХДАФК, 2010. № 1. С. 18-21.

10. Мерлин В.С. Психология индивидуальности: Избранные психологические труды. Москва: Издательство Московского психолого-социального института, 2009. 544 с.

11. Обозов Н.Н. Типы личности, темперамент и характер. Санкт-Петербург: Союз, 1998. 246 с.

12. Олійник В., Бегас I. Корекція темпераменту учнів молодшого шкільного віку у процесі розв'язування ними текстових задач (на прикладі флегматичного типу темпераменту). Актуальні проблеми психології: Зб. наук. праць Ін-ту психології ім. Г. Костюка НАПН України. Т. XI: Психологія особистості. Психологічна допомога особистості. 2017. Вип. 16. С. 134-137.

13. Прокоф'єва М.Ю. Урахування темпераменту в реалізації диференційованого підходу при навчанні молодших школярів. Вісник післядипломної освіти. 2012. Вип. 6. С. 79-85.

14. Психология индивидуальных различий: Хрестоматия по психологии. Под ред. Ю.Б. Гиппенрейтер, В.Я. Романова. Москва: АСТ-Астрель, 2008. 720 c.

15. Райгородский Д.Я. Практическая психодиагностика. Методики и тесты. Самара: Издательский дом «БАХРАХ-М», 2001. 672 с.

16. Юров И.А. Взаимосвязь физических качеств и психологических свойств спортсменов. Вестник спортивной науки. 2013. № 3. С. 23-28.

17. Юров И.А. Психодинамические корреляты спортивной успешности. Вестник спортивной науки. 2012. № 3. С. 22-26.

18. Anderson S.E., Bandini L.G., Dietz W.H., Must A. Relationship between temperament, nonresting
O.A., \& Chipyshev, A.V., \& Ryazancev, A.V. (2009). Razvitie psihodinamicheskih funkcij u uchashchihsya mladshih klassov s razlichnym urovnem umstvennyh nagruzok. [The development of psychodynamic functions in elementary school students with different levels of mental stress]. South Ural State University Bulletin. Series 15: Education, health, physical culture, 21, 39 (172), 19-23 (in Russian).

5. Dubrovina, I.V., \& Andreeva, A.D., \& Danilova, E.E., \& Vohmyanina, T.V. (1998). Psihokorrekcionnaya i razvivayushchaya rabota s det'mi. [Psychocorrectional and developmental work with children]. Moskva: Izdatel'skij centr «Akademiya», 160 (in Russian).

6. Dudin, S.I. (1994). O svyazi temperamenta s obshchimi sposobnostyami. [About the connection of temperament with general abilities]. Psychological Journal, 15, 2, 165-170 (in Russian).

7. Kan, Yu.B. (2014). Doslidzhennia rivnia fizychnoi pidhotovlenosti uchniv z riznymy psykhodynamichnymy vlastyvostiamy. [The study of physical fitness of students with different properties psychodynamic]. Scientific journal of National Pedagogical M.Dragomanov University. Series 15: Scientificpedagogical problems of physical culture, $3 \mathrm{~K}$ (44), 298-303 (in Ukrainian).

8. Kashapov, R.R. (2002). Tipologiya lichnosti, ili kakie my raznye. [Typology of personality, or what we are different]. Moskva: AST-PRESS KNIGA, 320 (in Russian).

9. Kibalnyk, O.Ya. (2010). Shliakhy pokrashchennia fizychnoi pidhotovlenosti uchniv pidlitkovoho viku. [Ways to improve the physical preparedness of adolescent students]. Slobozhanskyi Herald of Science and Sport. Kharkiv: KhDAFK, 1, 18-21 (in Ukrainian).

10. Merlin, V.S. (2009). Psihologiya individual'nosti: Izbrannye psihologicheskie trudy. [Psychology of personality: Selected psychological works.]. Moskva: Izdatel'stvo Moskovskogo psihologosocial'nogo instituta, 544 (in Russian).

11. Obozov, N.N. (1998). Tipy lichnosti, temperament $\mathrm{i}$ harakter. [Personality types, temperament and character]. Sankt-Peterburg: Soyuz, 246 (in Russian).

12. Oliinyk, V., \& Behas I. (2017). Korektsiia temperamentu uchniv molodshoho shkilnoho viku u protsesi rozviazuvannia nymy tekstovykh zadach (na prykladi flehmatychnoho typu temperamentu). [Correction of temperament for pupils of junior school age in the process of solving text problems (on the example of phlegmatic temperament)]. Actual problems of psychology: Collection of scientific papers of G. Kostyuk Institute of Psychology of the NAPS of Ukraine. Vol. XI: Psychology of personality. Psychological help of the person, 16, 134-137 (in Ukrainian). 
energy expenditure, body composition, and physical activity in girls. Int. J. Obes Relat Metab Disord. 2004. Vol. 28 (2). P. 300-306.

19. Delgado S.V. Psychodynamic psychotherapy for children and adolescents: an old friend revisited. Psychiatry. Edgmont, 2008. Vol. 5 (5), May. P. 6772.

20. Irwin J.D., Johnson A.M., Vanderloo L.M., Burke Sh.M., Tucker P. Temperament and Objectively Measured Physical Activity and Sedentary Time among Canadian Preschoolers. Preventive Medicine Reports. 2015. Vol. 2. P. 598-601.
13. Prokofieva, M.Yu. (2012). Urakhuvannia temperamentu $v$ realizatsii dyferentsiiovanoho pidkhodu pry navchanni molodshykh shkoliariv. [Accounting for temperament in implementing diferentiated approach for teaching elementaryschool]. Postgraduate Herald, 6, 79-85(in Ukrainian).

14. Psihologiya individual'nyh razlichij: Hrestomatiya po psihologii (2008). [Psychology of individual differences: Reading Psychology]. Red. Gippenrejter, YU.B., \& Romanova, V.YA.. Moskva: AST-Astrel', 720 (in Russian).

15. Rajgorodskij, D.Ya. (2001). Prakticheskaya psihodiagnostika. Metodiki i testy. [Practical psychodiagnostics. Methods and tests. Samara: Izdatel'skij dom «BAHRAH-M», 672 (in Russian).

16. Yurov, I.A. (2012). Psihodinamicheskie korrelyaty sportivnoj uspeshnosti. [Psychodynamic correlates of sporting success]. Journal of Sports Science, 3, 22-26 (in Russian).

17. Yurov, I.A. (2013). Vzaimosvyaz' fizicheskih kachestv i psihologicheskih svojstv sportsmenov. [The relationship of physical qualities and psychological properties of athletes]. Journal of Sports Science, 3, 23-28 (in Russian).

18. Anderson, S.E., \& Bandini, L.G., \& Dietz, W.H., \& Must, A. (2004). Relationship between temperament, nonresting energy expenditure, body composition, and physical activity in girls. Int. J. Obes Relat Metab Disord, 28 (2), 300-306 (in English).

19. Delgado, S.V. (2008). Psychodynamic psychotherapy for children and adolescents: an old friend revisited. Psychiatry. Edgmont, 5 (5), 67-72 (in English).

20. Irwin, J.D., \& Johnson, A.M., \& Vanderloo, L.M., \& Burke, Sh.M., \& Tucker, P. (2015). Temperament and Objectively Measured Physical Activity and Sedentary Time among Canadian Preschoolers. Preventive Medicine Reports, 2, 598-601 (in English).

\section{Бондарчук Наталія}

Ужгородський національний університет

м. Ужгород, вул. Грушевського, № 67, кв. 1, Україна

e-mail: nataliia.bondarchuk@uzhnu.edu.ua, тел. +38(050)7388501

Чернов Віктор Дмитрович

Ужгородський національний університет

м. Ужгород, вул. Гойди, № 1, кв. 3, Україна

e-mail: victor.chernov@ uzhnu.edu.ua, тел +38(066)8456139

\section{Kalabiska Irina}

Research Fellow, Assistant Professor

University of Physical Education

Research Center for Sport Physiology

1123 Budapest, Alkotás u. 44., Hungary

Email: kalabiskai@gmail.com

kalabiska.irina@tf.hu, Phone: +36-1-488-1537 